\title{
Effect of agrochemicals on macroinvertebrate assemblages in Pampasic streams, Buenos Aires, Argentina
}

\author{
Marina Solis $^{1} \cdot$ Hernán Mugni $^{1} \cdot$ Silvia Fanelli $^{1} \cdot$ Carlos Bonetto $^{1}$
}

Received: 27 September 2016/ Accepted: 7 February 2017

(C) Springer-Verlag Berlin Heidelberg 2017

\begin{abstract}
Agricultural practices have been intensified in recent decades in Argentina. The Pampa plain is the main agricultural region of the country. The effect of increased application of agrochemicals on the invertebrate fauna of the Pampasic streams remains unreported. In the present study, we compared the abundance and composition of invertebrate assemblages in seven Pampasic streams with contrasting soil use in their basins. Two streams run through intensively cropped plots, two drain basins with livestock fields, while the other three are located within a biosphere Reserve. Higher nutrient and insecticide concentrations were measured in the streams draining cropped basins, related with pesticide applications and crop fertilization. The invertebrate assemblage composition of the cropped streams differed significantly from the others and between the two. Present evidence suggests that the impact of agrochemicals results in a change in composition with decreased abundance or absence of sensitive species such as Hyalellidae, Caenidae, Baetidae and Curculionidae and increased abundance of more tolerant taxa: Ostracoda, Glossiphoniidae (Hirudinea), Ancylidae (Gundlanchia), Ampullariidae (Pomacea canaliculata), Sphaeriidae and Dugesiidae. Available information suggests that macrophyte cover and composition also influence the invertebrate assemblages of the Pampasic streams.
\end{abstract}

Keywords Macroinvertebrate assemblages - Pampasic streams $\cdot$ Pesticides $\cdot$ Nutrients $\cdot$ Soil use

Marina Solis

marinasolis@ilpla.edu.ar; marilinls@hotmail.com

1 ILPLA (Instituto de Limnología "Dr. Raúl A. Ringuelet”), UNLP, CONICET, FCNyM, Boulevard 120 y 62, La Plata, Buenos Aires, Argentina

\section{Introduction}

At present, there is increasing concern regarding the social and environmental costs caused by human practices such as deforestation and agriculture (Soldner et al. 2003). Agriculture (croplands and pasture) covers $15.3 \times 10^{6} \mathrm{~km}^{2}$ and represents the world's largest terrestrial biome (Stehle and Schulz 2015). Non-point source contamination with agrochemicals applied in agricultural production is considered the main cause of water quality degradation in inland waters (Schulz 2004). In the last decade, it was recognized that agriculture was associated with nutrient enrichment and pesticide loads in rural streams. Liess and Von der Ohe (2005) and Liess et al. (2008) found a relationship between insecticide exposure and the composition of the invertebrate community in Germany. Schafer et al. (2007) associated a decrease in relative abundance and number of sensitive invertebrate species with the stress caused by pesticide exposition in agricultural streams in France. Leonard et al. (1999) reported a decreased abundance of six taxa of macroinvertebrates in the Namoi River (Australia) in an area where irrigated cotton is treated with endosulfan.

Argentina increased its agricultural production in past decades as a consequence of the introduction of new technologies resulting in increased land productivity and of livestock. Within the new management practices introduced, the most significant was the steady increase in genetically modified soybean production since its release on the market in 1996. Soy and its byproducts (oil, flour, pellets) at present represent the main Argentine export, the world's third largest (Aizen and Harder 2009). Soybean cultivation in Argentina has increased from 30,800 ha in the seventies to 17.8 million ha in the 2014-2015 season (MAGyP 2016). Development of short-cycle varieties allowed two crops per season, wheat followed by soy. Soy 
is grown using direct seed management, a technique originally recommended to reduce erosion losses. The soil surface is not removed, seeds are placed in a small furrow, and fallow is attained by glyphosate applications. Soy was the main cause of increased agrochemicals consumption. Pesticide consumption increased from six million kilograms in 1992 (Pengue 2000) to 32 million kilograms in 2012 (CASAFE 2013). Fertilizer consumption increased at a rate of $18 \%$ per year from 174,000 tons per year in the 1991-2007 period, reaching 3,240,992 tons in 2013 (CIAFA 2016).

The Argentine Pampa is a large plain with mild weather and fertile soils that covers the central part of the country. The region amounts to roughly 60 million ha and accounts for about $60 \%$ of total Argentine crop production. Main insecticides applied have been glyphosate, cypermethrin, endosulfan and chlorpyrifos. Pesticides have been detected in rivers (Marino and Ronco 2005), suspended matter and bottom sediments in streams (Jergentz et al. 2004a, b, 2005; Hunt et al. 2016), and the air (Astoviza et al. 2015). However, the effect of agrochemicals exposure on the resident fauna remains unreported. The objective of the present work is to study the effect of agrochemicals application in the field on the invertebrate assemblages of the Pampasic streams draining basins of contrasting land use.

\section{Materials and methods}

\section{Study sites}

The studied streams are located in the Rio de la Plata coastal fringe, between La Plata and Magdalena, in Buenos
Aires province, Argentina (Fig. 1). The streams run roughly parallel in a west-east direction toward the Rio de la Plata. The climate is mild and humid; mean monthly temperatures range from $9.9{ }^{\circ} \mathrm{C}$ in July to $22.4{ }^{\circ} \mathrm{C}$ in January. Mean annual precipitation amounts to $1060 \mathrm{~mm}$ featuring small seasonal variations (Hurtado et al. 2006).

Seven streams with different land use in their basins were selected (Table 1). Two streams, Remes and Gato, drain cropped basins. The Remes stream, at the sampling point, runs through a farm where corn and soy are grown. The sampling site at the Gato stream is located in a rural area with horticultural crops, mainly tomatoes.

The Arregui and Sin Nombre streams drain basins where land use is livestock at low densities on natural grasslands. At the Arregui sampling site, the stream borders are separated from the adjacent plots by a fence leaving a 5-20 m strip of ungrazed grassland. The Sin Nombre stream, at the sampling site, runs through a plot in which cows move freely and enter the stream to drink.

Three studied streams, Confluencia, Destino and Morales, are located within the "Parque Costero Sur" biosphere Reserve (Athor 2009). The landscape is grassland with small patches of forest. At the Morales and Destino, cows were observed at the sampling sites.

The Pampa plain was originally covered by grasslands. Pampasic streams lack forested borders. Instead, large macrophyte stands develop within the streams. In the Remes and Sin Nombre, macrophytes cover, in summer, the whole water surface. In the Remes, Typha dominguensis and Ludwigia peploides were dominant. In the Sin Nombre, Ludwigia peploides was also dominant, accompanied by Hydrochleis nymphoides, Sagittaria montevidensis and Gymnocornis pinlantoides. In the

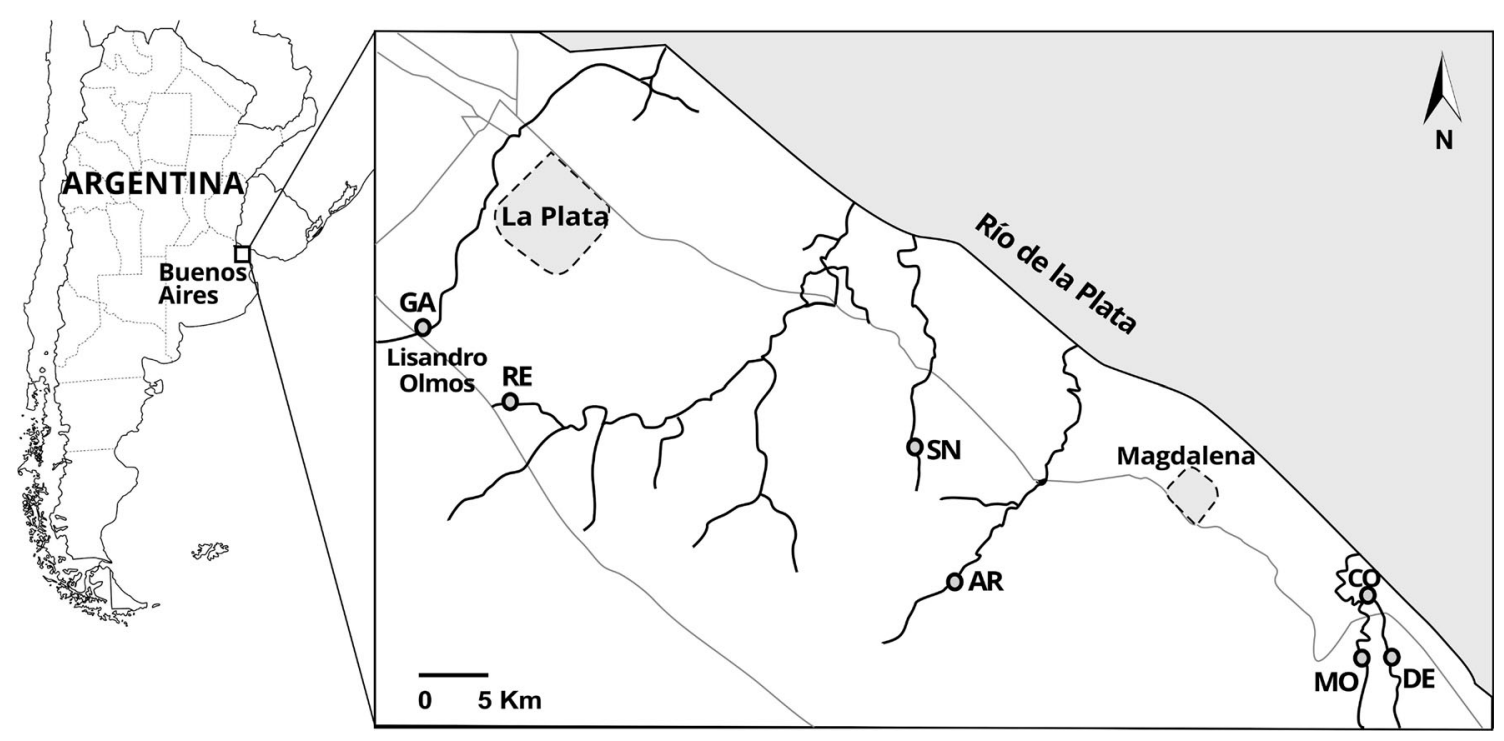

Fig. 1 Studied area and sampling sites 
Table 1 Sampling sites, localities and land use of the studied streams

\begin{tabular}{llll}
\hline Stream & Locality & Coordinates & Land use \\
\hline Destino (De) & Magdalena & $35^{\circ} 8^{\prime} 15.35^{\prime \prime} \mathrm{S} ; 57^{\circ} 23^{\prime} 40.21^{\prime \prime} \mathrm{W}$ & Reserve \\
Morales (Mo) & Magdalena & $35^{\circ} 8^{\prime} 17.54^{\prime \prime} \mathrm{S} ; 57^{\circ} 23^{\prime} 57.74^{\prime \prime} \mathrm{W}$ & Reserve \\
Confluencia (Co) & Magdalena & $35^{\circ} 7^{\prime} 53.10^{\prime \prime} \mathrm{S} ; 57^{\circ} 24^{\prime} 1.47^{\prime \prime} \mathrm{W}$ & Reserve \\
Arregui (Ar) & Mansilla & $35^{\circ} 7^{\prime} 22.1^{\prime \prime} \mathrm{S} ; 57^{\circ} 41^{\prime} 11.6^{\prime \prime} \mathrm{W}$ & Livestock \\
Sin Nombre (SN) & Mansilla & $35^{\circ} 2^{\prime} 22.8^{\prime \prime} \mathrm{S} ; 57^{\circ} 42^{\prime} 40.5^{\prime \prime} \mathrm{W}$ & Livestock \\
Remes (Re) & Olmos & $35^{\circ} 1^{\prime} 31.87^{\prime \prime} \mathrm{S} ; 57^{\circ} 59^{\prime} 39.6^{\prime \prime} \mathrm{W}$ & Crops \\
Gato $(\mathrm{Ga})$ & Olmos & $34^{\circ} 58^{\prime} 53.8^{\prime \prime} \mathrm{S} ; 58^{\circ} 3^{\prime} 12.1^{\prime \prime} \mathrm{W}$ & Crops \\
\hline
\end{tabular}

\section{Pesticide analysis}

Morales and Destino, floating macrophytes were dominant L. peploides and Myriophyllum aquaticum were dominant in the Destino accompanied by G. spinlantoides, while Azolla filiculoides was dominant in the Morales. Confluencia, Arregui and Gato showed lower macrophyte cover, Schoenoplectus californicus being the dominant species, accompanied by A. filiculoides in the Confluencia and $L$. peploides in the Gato. Occasionally, algal mats developed among the Schoenoplectus stems in the Arregui and Gato.

The streams were sampled 10 times in the period from December 2012 to October 2013. The Morales, Destino and Gato streams dried up during the 2012-2013 summer drought and were sampled eight times from February to October 2013. On April 2, 2013, an exceptional rain event caused inundation in the surroundings of La Plata city. Precipitation amounted $273 \mathrm{~mm}$ in the Experimental Field Station of the School of Agronomic Science, $\left(35^{\circ} 01^{\prime} \mathrm{S}\right.$, $57^{\circ} 59^{\prime} \mathrm{W}$ ), about three to five $\mathrm{km}$ from the Remes and Gato sampling sites, respectively (Fig. 1). Precipitation data in the southern streams (Arregui, Sin Nombre, Confluencia, Destino and Morales) are not available. In order to assess the effect of this exceptional event, emphasis was placed on comparing the assemblage composition in Remes and Gato streams on the previous sampling date against that of the following one, 15 days later.

\section{Environmental variables}

Dissolved oxygen, temperature, conductivity $\mathrm{pH}$ and turbidity in stream water were measured in situ with multiparameter equipment (Yellow Springs instruments SI 556).

Water samples were immediately filtered through Whatman GF/C filters and carried in coolers to the laboratory. Suspended matter (SM) was determined as the weight difference after filtration. Dry filters were extracted after $24 \mathrm{~h}$ with acetone under refrigeration for chlorophyll determination, following Lorenzen (1967). Dissolved nutrients were determined in the filtrate. Soluble reactive phosphorus (SRP, molybdate-ascorbic), nitrite $\left(\mathrm{NO}_{2}{ }^{-}\right.$, diazotation), nitrate $\left(\mathrm{NO}_{3}{ }^{-}\right.$, hydrazine reduction followed by diazotation) and ammonium $\left(\mathrm{NH}_{4}{ }^{+}\right.$, indophenol blue) were determined following APHA (1995).
Sediment samples were collected for pesticide analysis to coincide with the invertebrate sampling from December 2012 until April 2013, which is the period of pesticide application in the main crops (soy and corn) and horticulture (tomatoes). Samples were taken with a stainless steel scoop from the top $2 \mathrm{~cm}$ and placed in amber glass jars. The samples were kept in coolers on ice until arrival at the laboratory where they were kept refrigerated until extraction (maximum five days). Sediments were extracted with a mixture of acetone and methylene chloride following You et al. (2004). Cleanup procedures were carried out using Florosil solid-phase extraction (SPE) cartridges (EPA 2007a, b, c). The following insecticides were measured: alpha BHC, delta BHC, aldrin, dieldrin, endrin, endosulfan I and II, endosulfan sulfate, lindane, heptachlor, heptachlor epoxide, DDD, DDT and methoxychlor, chlorpyrifos, malathion and methyl parathion. The sample extracts were injected into a GC-ECD (Thermo Scientific 1300), following EPA method 8081 A (1996); equipped with a HP5 column, $30 \mathrm{~m}$ and $0.32 \mathrm{ID}$, $\mathrm{N} 2$ carrier, ramp and detector temperatures were: $100{ }^{\circ} \mathrm{C}$ ( $\left.3 \mathrm{~min}\right), 15^{\circ} \mathrm{C} / \mathrm{min}$ to $300{ }^{\circ} \mathrm{C}$, Hold $3 \mathrm{~min}$. Solvents used were J. T. Baker for pesticide analysis. Standards utilized for calibration were Accustandard mixed organochlorine and organophosphorous pesticides. Detection limit of the analyzed pesticides was $0.5 \mathrm{ng} / \mathrm{g} \mathrm{dw}$.

\section{Macroinvertebrate sampling}

Macroinvertebrates were sampled from emergent vegetation by means of a D-net of $500 \mu \mathrm{m}$ pore size and $30 \mathrm{~cm}$ diameter. At each site, three sweeps were collected, covering an area of approximately $1 \mathrm{~m}^{2}$ per sample. Samples were preserved with $80 \%$ alcohol and taken to the laboratory for sorting. All invertebrates were later identified under a stereoscopic microscope. Taxa were identified to (2009) and Merritt et al. (2008). family or genus following Domínguez and Fernández 


\section{Statistical analysis}

Environmental measurements at the different sites were compared by means of the analysis of variance (ANOVA) followed by the Dunn's Method or Tukey test at a significance level of $p<0.05$. Statistical assumptions of homogeneity (Levene) and normality (Kolmogorov-Smirnov) were checked; whenever assumptions were not substantiated the Kruskal-Wallis, nonparametric ANOVA by ranks test was used. Relationships among measured environmental variables were assessed by means of the Pearson product moment correlation. All statistical analyses were performed using SigmaStat 3.5 software, at a significant level of $p<0.05$.

Community structure was assessed using metrics describing taxon composition, richness, abundances and percent abundance of the main orders. Total abundance for each taxon was estimated and reported in terms of number of individuals per surface unit (ind. $\mathrm{m}^{-2}$ ). Abundance and richness were calculated using the multivariate statistical package PRIMER version 5 (Clarke and Gorley 2001). Comparison of abundance and richness at different sampling sites was performed using analysis of variance (ANOVA).

For comparison between abundances of each taxon in the samplings previous to and following the exceptional rain event of $273 \mathrm{~mm}$, a nonparametric test of paired samples was used (Wilcoxon test). With the object of assessing habitat delimitation as a function of land use, a cluster analysis was performed. Abundance data at each date and sampling site were used and transformed by a log $(x+1)$ function to reduce the contribution of the dominant groups. Data were analyzed using the Bray Curtis similarity index.

Differences in the assemblage composition among sites were assessed by means of the analysis of similarity (ANOSIM). The percentage of similarity (SIMPER) was calculated to assess the taxa that contributed most to the differences in the assemblages among sites (Clarke and Warwick 2001).

Olmstead-Tukey diagrams were used to rank the different taxa (Sokal and Rohlf 1979). Taxa with abundances and frequency higher than the mean were classified as dominant. Taxa with frequencies higher than the mean and abundance lower than the mean were considered constant. Higher densities than the mean and lower frequencies were considered occasional. Lower densities and frequency than the mean were considered rare.

\section{Results}

\section{Environmental variables}

Environmental variables were rather similar in the studied streams (Table 2). No significant differences were detected

Table 2 Environmental variables and nutrient concentrations measured at the studied sites, means (variation ranges)

\begin{tabular}{|c|c|c|c|c|c|c|c|}
\hline & Co & $\mathrm{De}$ & Mo & $\mathrm{Ar}$ & SN & $\mathrm{Re}$ & $\mathrm{Ga}$ \\
\hline $\begin{array}{c}\text { Number of } \\
\text { samples }\end{array}$ & 10 & 8 & 8 & 10 & 10 & 10 & 8 \\
\hline $\mathrm{T}\left({ }^{\circ} \mathrm{C}\right)$ & $16(6-34)$ & $13(6-17)$ & $13(6-18)$ & $16(6-31)$ & $18(7-31)$ & $15(8-25)$ & $14(9-19)$ \\
\hline Depth $(\mathrm{cm})$ & $37(15-90)$ & $34(10-50)$ & $27(10-50)$ & $23(7-40)$ & $35(20-50)$ & $34(20-50)$ & $54(45-65)$ \\
\hline Width (m) & $8(5-9)$ & $12(8-16)$ & $6(5-8)$ & $5(4-7)$ & $8(5-16)$ & $6(3-12)$ & $4(3-7)$ \\
\hline $\begin{array}{l}\text { Conduct. } \\
(\mu \mathrm{S} / \mathrm{cm})\end{array}$ & $424(234-741)$ & $428(222-830)$ & $432(234-1058)$ & $864(471-1251)$ & $\begin{array}{l}144 \\
(87-239)\end{array}$ & $277(149-624)$ & $536(239-940)$ \\
\hline $\mathrm{pH}$ & $6.9(5.8-7.5)$ & $7.1(6.4-7.6)$ & $6.7(6.4-7.1)$ & $7.5(6.7-8.1)$ & $7.0(6.2-8.6)$ & $7.3(6.8-7.9)$ & $7.8(6.7-8.8)$ \\
\hline $\mathrm{DO}(\mathrm{mg} / \mathrm{l})$ & $7(2-13)$ & $8(3.5-13)$ & $6(3-14)$ & $9(4-13)$ & $9(1-14)$ & $8(1-16)$ & $11(4-23)$ \\
\hline $\begin{array}{l}\text { Susp. Matter } \\
(\mathrm{mg} / \mathrm{l})\end{array}$ & $64(22-162)$ & $46(20-84)$ & $122(10-322)$ & $24(7-66)$ & $90(17-321)$ & $35(8-140)$ & $16(8-39)$ \\
\hline Turbidity (NTU) & $93(23-178)$ & $84(60-122)$ & $193(53-461)$ & $31(15-59)$ & $\begin{array}{l}126 \\
(17-474)\end{array}$ & $47(15-169)$ & $39(11-104)$ \\
\hline $\begin{array}{l}\text { Chlorophyll ( } \mu \mathrm{g} / \\
\text { 1) }\end{array}$ & $13($ nd -38$)$ & $17(\mathrm{nd}-57)$ & $27(\mathrm{nd}-57)$ & $7(\mathrm{nd}-16)$ & $62(\mathrm{nd}-202)$ & $36(\mathrm{nd}-131)$ & $18(\mathrm{nd}-36)$ \\
\hline $\mathrm{N}-\mathrm{NO}_{3}{ }^{-}(\mu \mathrm{g} / \mathrm{l})$ & $87(\mathrm{nd}-158)$ & $80($ nd -129$)$ & $136(\mathrm{nd}-467)$ & 580 (nd -4922) & $\begin{array}{l}200 \\
\quad(\mathrm{nd}-1265)\end{array}$ & $236($ nd -923$)$ & $\begin{array}{l}2442 \\
\quad(361-7737)\end{array}$ \\
\hline $\mathrm{N}^{-\mathrm{NO}_{2}}{ }^{-}(\mu \mathrm{g} / \mathrm{l})$ & $24(12-39)$ & $19(11-46)$ & $21(\mathrm{nd}-49)$ & $11(\mathrm{nd}-26)$ & $14($ nd 28) & $15(\mathrm{nd}-36)$ & $105(22-255)$ \\
\hline $\mathrm{N}-\mathrm{NH}_{4}{ }^{+}(\mu \mathrm{g} / \mathrm{l})$ & $32(\mathrm{nd}-70)$ & $15($ nd -44$)$ & $28(\mathrm{nd}-146)$ & $55(\mathrm{nd}-160)$ & $16(\mathrm{nd}-47)$ & $38($ nd -114$)$ & $213(9-1097)$ \\
\hline $\mathrm{SRP}(\mu \mathrm{g} / \mathrm{l})$ & $38(\mathrm{nd}-76)$ & $32($ nd -91$)$ & $34($ nd -119$)$ & $271(49-839)$ & $\begin{array}{l}243(27 \\
-1116)\end{array}$ & $\begin{array}{l}1038 \\
\quad(15-7075)\end{array}$ & $\begin{array}{l}865 \\
\quad(108-3798)\end{array}$ \\
\hline
\end{tabular}

Sampling period: December 2012-October 2013

$n d$ nutrient detection limit $5 \mu \mathrm{g} / \mathrm{l}$, chlorophyll $0.8 \mu \mathrm{g} / \mathrm{l}$ 
in oxygen and chlorophyll concentrations. Remes and Sin Nombre, the streams with highest macrophyte cover, attained low oxygen concentrations $(0.9-1 \mathrm{mg} / \mathrm{l})$ in summer (December-January). Nutrient concentrations significantly differed among streams. The Gato stream showed higher nitrate concentrations than the livestock and Reserve streams, higher nitrite concentrations than the Sin Nombre, Arregui, and Remes and higher ammonia concentrations than the Sin Nombre and Destino. Nitrite and nitrate were correlated to ammonia concentrations ( $r=0.59 \mathrm{y}, r=0.72$, respectively; $p<0.05$ ). SRP concentrations were significantly higher in the streams adjacent to cropped plots than streams in the Reserve. Arregui concentrations were also higher than in the Morales and Destino streams. Unusually high SRP concentrations measured in summer at the Remes and Sin Nombre were coincident with the lowest oxygen concentrations and maximum macrophyte cover of $L$. peploides, being seven times higher in the Remes.

\section{Pesticides}

Either endosulfan or its degradation product endosulfan sulfate was detected at most sites. Endosulfan sulfate was highest in the Remes cropped stream, while concentrations in the Reserve streams amounted to a few nanograms per gram dry weight of sediment (Table 3). Similarly, DDT, its degradation product DDE, or Heptachlor, were detected in all streams, concentrations being found to be an order of magnitude higher in the Gato and Remes cropped streams.

\section{Macroinvertebrate assemblages}

A total amount of 17,226 specimens were identified, belonging to 66 taxa, and 14 orders (Table 4). Crustacea, mainly Hyalellidae, was the dominant group, except in the Remes, where Diptera, mainly Chironomidae, was the dominant group. Mollusca was the second most abundant group in the Destino, Morales, Sin Nombre and Remes. Hirudinea was well represented in the Remes while being present at low abundances in the Reserve and livestock streams. Ephemeroptera and Odonata were absent from the Gato, although well represented in the Reserve and livestock streams. Platyhelminthes was absent from the Reserve and was only detected in the cropped and Arregui streams. Trichoptera was only found in the Sin Nombre at low densities. Lepidoptera was only present in the Confluencia stream (Table 4).

While most groups were represented in all streams, lower abundances were recorded in the cropped streams. Mean abundance was significantly higher in the Sin Nombre and Destino than in the Remes and Gato and was higher in the Confluencia and Morales than in the Gato. The taxonomic richness was significantly higher in the Reserve and Sin Nombre than in the Gato and Arregui streams and higher in the Sin Nombre than in the Remes (Table 4).

Large taxonomic groups exhibited a major seasonal variability. Crustacea showed the largest temporal variability in the Reserve and livestock streams, going from low summer densities $\left(1-3 \mathrm{ind} / \mathrm{m}^{2}\right)$ up to high fall and spring peaks (300-1225 ind $\left./ \mathrm{m}^{2}\right)$. By contrast, in the cropped streams, Crustacea was absent from the Remes in most samplings, and from the Gato in one sampling, and maximum densities amounted to only 10 and $35 \mathrm{ind} / \mathrm{m}^{2}$, respectively. On the other hand, Chironomidae showed a comparatively high maximum in the Remes, in October $\left(281 \mathrm{ind} / \mathrm{m}^{2}\right)$, while in the other streams maximum densities amounted to $20-197 \mathrm{ind} / \mathrm{m}^{2}$.

Invertebrate abundance in Remes $\left(33-31 \mathrm{ind} / \mathrm{m}^{2}\right)$ and Gato $\left(25-27 \mathrm{ind} / \mathrm{m}^{2}\right)$ was not significantly different in the samplings prior to and following the extraordinary rain event of $273 \mathrm{~mm}$ fallen on April 2, 2013.

The cluster analysis registered a clear segregation in the invertebrate assemblages of the cropped streams (Global $R=0.854, p<0.001)$. Most samplings in the Gato and Remes were joined together in groups A, B and H (Fig. 2), except two summer samplings in the Remes that were joined together in group $\mathrm{C}$, together with the Confluencia and Arregui. Livestock and Reserve streams were not
Table 3 Insecticide concentration in surficial sediments at the studied sites, in $\mathrm{ng} / \mathrm{g}$ sed dw. Only the samplings with at least one detectable value are shown. No detectable concentrations were determined in the Morales and Arregui streams at any point in the present study and were omitted from the table

\begin{tabular}{|c|c|c|c|c|c|c|c|c|c|c|}
\hline \multirow[t]{2}{*}{$\mathrm{ng} / \mathrm{g}$} & \multirow{2}{*}{$\begin{array}{l}\text { Co } \\
\text { Feb } \\
2013\end{array}$} & \multirow{2}{*}{$\begin{array}{l}\text { De } \\
\text { Dec } \\
2012\end{array}$} & \multicolumn{2}{|l|}{$\mathrm{SN}$} & \multicolumn{4}{|l|}{$\operatorname{Re}$} & \multicolumn{2}{|l|}{$\mathrm{Ga}$} \\
\hline & & & $\begin{array}{l}\text { Dec } \\
2012\end{array}$ & $\begin{array}{l}\text { Feb } \\
2013\end{array}$ & $\begin{array}{l}\text { Dec } \\
2012\end{array}$ & $\begin{array}{l}\text { Jan } \\
2013\end{array}$ & $\begin{array}{l}\text { Feb } \\
2013\end{array}$ & $\begin{array}{l}\text { Apr } \\
2013\end{array}$ & $\begin{array}{l}\text { Jan } \\
2013\end{array}$ & $\begin{array}{l}\text { Apr } \\
2013\end{array}$ \\
\hline Endosulfan I & 18 & $\mathrm{Nd}$ & $\mathrm{Nd}$ & $\mathrm{Nd}$ & $\mathrm{Nd}$ & $\mathrm{Nd}$ & $\mathrm{Nd}$ & $\mathrm{Nd}$ & $\mathrm{Nd}$ & $\mathrm{Nd}$ \\
\hline Endosulfan II & $\mathrm{Nd}$ & $\mathrm{Nd}$ & 21 & 6 & $\mathrm{Nd}$ & $\mathrm{Nd}$ & 3 & $\mathrm{Nd}$ & 8 & $\mathrm{Nd}$ \\
\hline Endosulfan Sulfate & $\mathrm{Nd}$ & 4 & $\mathrm{Nd}$ & $\mathrm{Nd}$ & $\mathrm{Nd}$ & 51 & $\mathrm{Nd}$ & $\mathrm{Nd}$ & $\mathrm{Nd}$ & $\mathrm{Nd}$ \\
\hline Heptachlor & $\mathrm{Nd}$ & $\mathrm{Nd}$ & 17 & 16 & $\mathrm{Nd}$ & 40 & 19 & 110 & 21 & 269 \\
\hline p-p' DDD & 6 & 1 & 8 & 4 & $\mathrm{Nd}$ & 9 & $\mathrm{Nd}$ & $\mathrm{Nd}$ & 6 & 57 \\
\hline p-p' DDT & $\mathrm{Nd}$ & $\mathrm{Nd}$ & $\mathrm{Nd}$ & $\mathrm{Nd}$ & 4 & 2 & $\mathrm{Nd}$ & 41 & $\mathrm{Nd}$ & 39 \\
\hline
\end{tabular}

Detection limit: $0.5 \mathrm{ng} / \mathrm{g} \mathrm{dw}$ 
Table 4 Abundance (ind $\mathrm{m}^{-2}$ ) of each taxon, mean abundance and richness at each site during the studied period

\begin{tabular}{|c|c|c|c|c|c|c|c|c|c|}
\hline Phylum/order & Suborder/family & Taxa & Co & De & Mo & $\mathrm{Ar}$ & $\mathrm{SN}$ & $\operatorname{Re}$ & $\mathrm{Ga}$ \\
\hline Platyhelminthes & & & 0 & 0 & 0 & 7 & 0 & 7 & 13 \\
\hline Tricladida & Dugesiidae & Dugesiidae & 0 & 0 & 0 & 7 & 0 & 7 & 13 \\
\hline Annelida & & & 4 & 10 & 22 & 2 & 18 & 94 & 17 \\
\hline Rhynchobdellida & Glossiphoniidae & Glossiphoniidae & 4 & 10 & 22 & 2 & 18 & 94 & 17 \\
\hline \multirow[t]{7}{*}{ Mollusca } & & & 162 & 442 & 816 & 26 & 1115 & 133 & 19 \\
\hline & Sphaeriidae & Sphaeriidae 1 & 0 & 0 & 1 & 0 & 1 & 15 & 0 \\
\hline & Sphaeriidae & Sphaeriidae 2 & 0 & 0 & 0 & 0 & 9 & 19 & 0 \\
\hline & Ancylidae & Gundlachia & 2 & 12 & 11 & 3 & 73 & 11 & 1 \\
\hline & Planorbidae & Biomphalaria peregrina & 29 & 429 & 803 & 17 & 1025 & 36 & 5 \\
\hline & Ampullariidae & Pomacea canaliculata & 126 & 1 & 1 & 6 & 7 & 57 & 12 \\
\hline & Physidae & Stenephysa marmorata & 5 & 0 & 0 & 0 & 0 & 1 & 1 \\
\hline Crustacea & & & 1106 & 2452 & 1141 & 1644 & 2195 & 78 & 66 \\
\hline Decapoda & Palaemonidae & Palaemonetes argentinus & 3 & 0 & 0 & 10 & 0 & 0 & 0 \\
\hline Amphipoda & Hyalellidae & Hyalella & 1101 & 2408 & 1086 & 1634 & 1683 & 21 & 65 \\
\hline Podocopida & Cyprididae & Cyprididae & 2 & 44 & 55 & 0 & 512 & 57 & 1 \\
\hline \multicolumn{10}{|l|}{ Insecta } \\
\hline \multirow[t]{2}{*}{ Trichoptera } & & & 0 & 0 & 0 & 0 & 6 & 0 & 0 \\
\hline & Limnephilidae & Verger & 0 & 0 & 0 & 0 & 6 & 0 & 0 \\
\hline \multirow[t]{4}{*}{ Ephemeroptera } & & & 104 & 132 & 95 & 115 & 413 & 7 & 0 \\
\hline & Baetidae & Callibaetis & 14 & 0 & 0 & 0 & 0 & 0 & 0 \\
\hline & & Baetidae & 75 & 116 & 95 & 22 & 409 & 7 & 0 \\
\hline & Caenidae & Caenidae & 15 & 16 & 0 & 93 & 4 & 0 & 0 \\
\hline \multirow[t]{7}{*}{ Odonata } & & & 159 & 284 & 54 & 51 & 343 & 47 & 0 \\
\hline & Anisoptera & Aeshnidae & 1 & 2 & 0 & 0 & 7 & 7 & 0 \\
\hline & & Libellulidae & 6 & 15 & 4 & 0 & 16 & 0 & 0 \\
\hline & & Anisoptera undetermined & 0 & 1 & 0 & 1 & 2 & 0 & 0 \\
\hline & Zygoptera & Coenagrionidae & 0 & 1 & 0 & 0 & 0 & 0 & 0 \\
\hline & & Lestidae & 0 & 1 & 0 & 0 & 29 & 0 & 0 \\
\hline & & Zygoptera undetermined & 152 & 264 & 50 & 50 & 289 & 40 & 0 \\
\hline \multirow[t]{11}{*}{ Heteroptera } & & & 50 & 73 & 62 & 12 & 109 & 43 & 7 \\
\hline & Corixidae & Corixini & 4 & 3 & 9 & 3 & 25 & 18 & 0 \\
\hline & & Sigara & 1 & 1 & 0 & 0 & 1 & 3 & 0 \\
\hline & Belostomatidae & Belostomatinae & 10 & 0 & 0 & 4 & 10 & 0 & 1 \\
\hline & & Belostoma & 18 & 43 & 14 & 4 & 42 & 18 & 3 \\
\hline & Notonectidae & Notonecta & 2 & 11 & 14 & 0 & 19 & 2 & 0 \\
\hline & & Notonectidae & 1 & 1 & 0 & 0 & 4 & 0 & 0 \\
\hline & Pleidae & Neoplea & 13 & 13 & 18 & 0 & 5 & 1 & 0 \\
\hline & Nepidae & Curicta & 0 & 0 & 1 & 0 & 0 & 0 & 0 \\
\hline & Aphidoidea & Aphidoidea & 0 & 0 & 0 & 1 & 0 & 1 & 3 \\
\hline & Hebridae & Lipogomphus & 1 & 1 & 6 & 0 & 3 & 0 & 0 \\
\hline
\end{tabular}


Table 4 continued

\begin{tabular}{|c|c|c|c|c|c|c|c|c|c|}
\hline Phylum/order & Suborder/family & Taxa & Co & $\mathrm{De}$ & Mo & $\mathrm{Ar}$ & $\mathrm{SN}$ & $\mathrm{Re}$ & $\mathrm{Ga}$ \\
\hline \multirow[t]{26}{*}{ Coleoptera } & & & 370 & 113 & 270 & 74 & 649 & 95 & 30 \\
\hline & Curculionidae & Curculionidae & 63 & 7 & 65 & 2 & 20 & 1 & 1 \\
\hline & Haliplidae & Haliplus & 0 & 0 & 0 & 0 & 3 & 0 & 0 \\
\hline & Crysomelidae & Crysomelidae & 0 & 0 & 0 & 0 & 6 & 2 & 1 \\
\hline & Staphylinidae & Staphylinidae & 0 & 0 & 1 & 0 & 1 & 0 & 0 \\
\hline & Noteridae & Hydrocanthus & 42 & 22 & 25 & 5 & 28 & 3 & 1 \\
\hline & & Suphis & 0 & 0 & 1 & 0 & 0 & 0 & 0 \\
\hline & Scirtidae & Scirtidae & 20 & 0 & 0 & 0 & 0 & 2 & 0 \\
\hline & Hydrophilidae & Tropisternus & 39 & 41 & 31 & 0 & 79 & 18 & 2 \\
\hline & & Berosus & 4 & 2 & 2 & 10 & 4 & 4 & 1 \\
\hline & & Derallus & 8 & 1 & 5 & 1 & 15 & 1 & 0 \\
\hline & & Enochrus & 26 & 1 & 13 & 22 & 83 & 30 & 5 \\
\hline & & Anacaenini undetermined & 17 & 3 & 1 & 8 & 28 & 8 & 1 \\
\hline & & Hydrobiomorpha & 11 & 0 & 17 & 0 & 10 & 0 & 0 \\
\hline & & Helochares & 1 & 0 & 2 & 1 & 1 & 0 & 0 \\
\hline & & Hydrophilidae undetermined & 7 & 1 & 0 & 0 & 0 & 1 & 5 \\
\hline & & Crenitis & 0 & 0 & 0 & 0 & 0 & 1 & 0 \\
\hline & Hydrochidae & Hydrochus & 1 & 0 & 0 & 0 & 2 & 1 & 0 \\
\hline & Dytiscidae & Bidessini & 91 & 12 & 72 & 23 & 242 & 15 & 10 \\
\hline & & Thermonectus & 0 & 1 & 0 & 0 & 1 & 0 & 0 \\
\hline & & Laccophilus & 26 & 10 & 14 & 0 & 62 & 4 & 0 \\
\hline & & Laccodytes & 12 & 9 & 19 & 2 & 61 & 4 & 1 \\
\hline & & Lancetes & 0 & 0 & 0 & 0 & 1 & 0 & 0 \\
\hline & & Megadytes & 1 & 3 & 1 & 0 & 1 & 0 & 0 \\
\hline & Elmidae & Elmidae & 0 & 0 & 1 & 0 & 0 & 0 & 0 \\
\hline & Heteroceridae & Heteroceridae & 1 & 0 & 0 & 0 & 1 & 0 & 2 \\
\hline \multirow[t]{10}{*}{ Diptera } & & & 686 & 245 & 346 & 101 & 150 & 303 & 40 \\
\hline & Chironomidae & Chironomidae & 219 & 192 & 233 & 80 & 106 & 298 & 28 \\
\hline & Culicidae & Culicidae & 9 & 10 & 5 & 2 & 31 & 0 & 2 \\
\hline & Tabanidae & Tabanidae & 3 & 1 & 6 & 0 & 0 & 0 & 0 \\
\hline & Stratiomyidae & Stratiomyidae & 440 & 35 & 99 & 10 & 4 & 4 & 4 \\
\hline & Ceratopogonidae & Ceratopogonidae & 10 & 5 & 3 & 8 & 1 & 1 & 0 \\
\hline & Ephydridae & Ephydridae & 2 & 0 & 0 & 1 & 7 & 0 & 6 \\
\hline & Muscidae & Muscidae & 0 & 0 & 0 & 0 & 1 & 0 & 0 \\
\hline & Tipulidae & Tipulidae & 0 & 2 & 0 & 0 & 0 & 0 & 0 \\
\hline & Simulidae & Simulidae & 3 & 0 & 0 & 0 & 0 & 0 & 0 \\
\hline \multirow[t]{2}{*}{ Lepidoptera } & & & 5 & 0 & 0 & 0 & 0 & 0 & 0 \\
\hline & & Lepidoptera & 5 & 0 & 0 & 0 & 0 & 0 & 0 \\
\hline Mean Abundance & & & 241 & 341 & 255 & 185 & 454 & 73 & 17 \\
\hline Mean richness & & & 23 & 23 & 23 & 13 & 24 & 16 & 10 \\
\hline
\end{tabular}

segregated in different groups. The Sin Nombre (livestock), Morales and Destino (Reserve) were joined together in groups E and D. The Sin Nombre, Morales and Destino share a dense macrophyte cover composed mainly of emergent and floating macrophytes. The Confluencia (Reserve) and Arregui (livestock) were joined together in groups $\mathrm{C}$ and $\mathrm{F}$, together with two samplings of the Remes in $\mathrm{C}$ and one of the Destino in F. The Confluencia and Gato share a comparatively low macrophyte cover dominated by S. californicus.

The ANOSIM analysis showed significant differences among the assemblages of the different streams (Global $R=0.448 ; p=0.001)$. Table 5 shows paired comparisons. The assemblages in the cropped streams were 


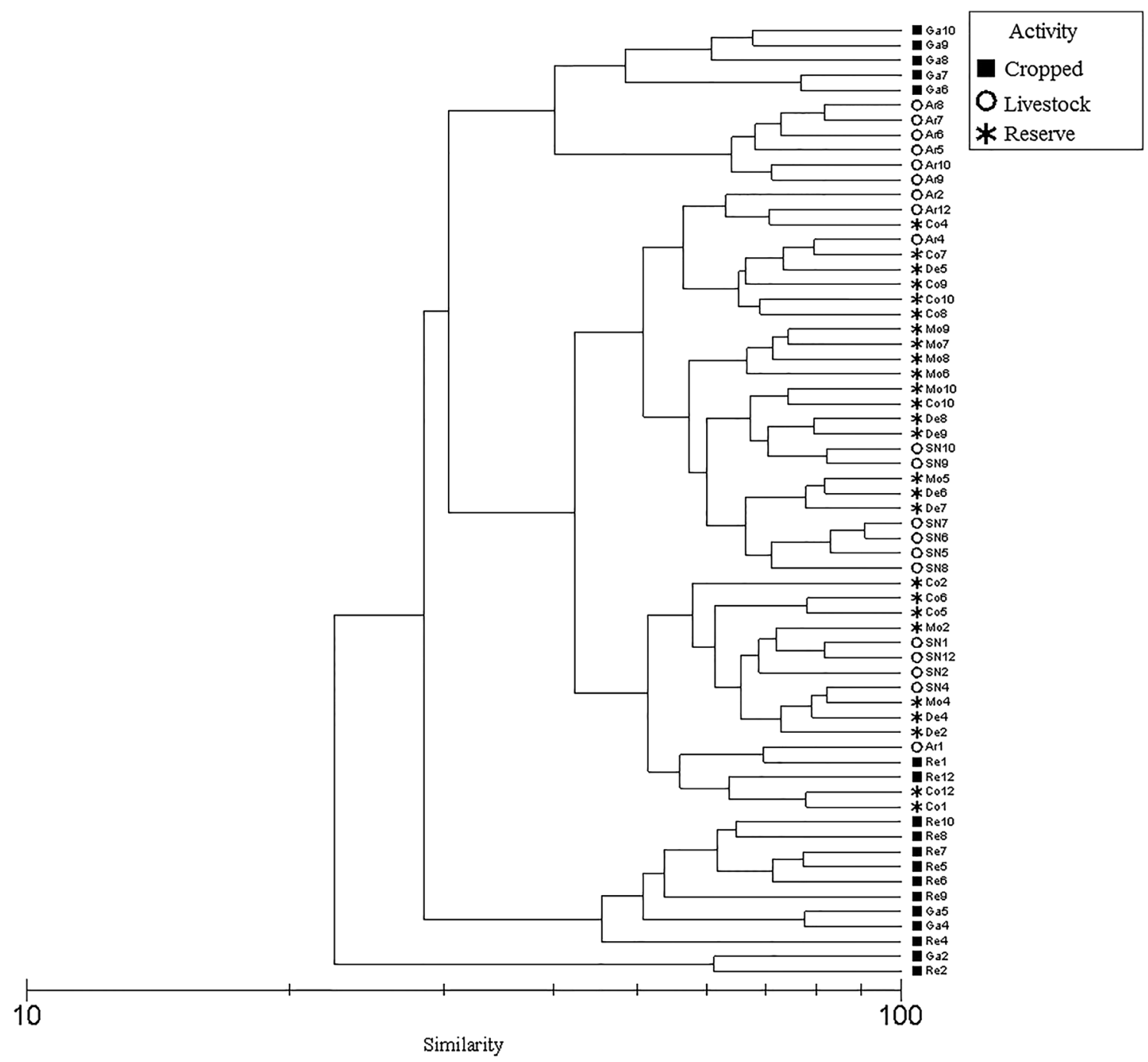

Fig. 2 Cluster of the invertebrate assemblages in the studied period. Re Remes, Ga Gato, SN Sin Nombre, Ar Arregui, Co Confluencia, De Destino, Mo Morales. Numbers 1 through 12 refer to the month of each sampling date

Table 5 ANOSIM correlation values, significance levels and percentage of dissimilarity for paired streams

\begin{tabular}{llll}
\hline Groups & R statistic & Sig. level $\%$ & Average dissimilarity \\
\hline Gato versus SN & 0.793 & 0.001 & 79.53 \\
Arregui versus SN & 0.746 & 0.001 & 65.49 \\
Gato versus Destino & 0.708 & 0.001 & 77.02 \\
Remes versus Arregui & 0.701 & 0.001 & 75.74 \\
Gato versus Confluencia & 0.635 & 0.001 & 75.29 \\
Arregui versus Destino & 0.586 & 0.001 & 58.36 \\
Remes versus Confluencia & 0.566 & 0.001 & 70.33 \\
Arregui versus Morales & 0.564 & 0.001 & 61.05 \\
Remes versus Destino & 0.558 & 0.002 & 66.31 \\
Gato versus Morales & 0.556 & 0.001 & 72.06 \\
Gato versus Arregui & 0.554 & 0.001 & 71.32 \\
Remes versus SN & 0.514 & 0.001 & 66.06 \\
Gato versus Remes & 0.447 & 0.001 & 74.48 \\
\hline
\end{tabular}


different from all the others and between each other, except the Remes and Morales, which were not significantly different. The assemblages in the Arregui were also different from those in all other streams, except the Confluencia. The assemblages of the Reserve streams and SN were significantly different from the cropped and Arregui streams, but were not found to be different among themselves.

The SIMPER analysis identified 16 taxa as the main contributors to the dissimilarity among the paired streams which were found to be significantly different. Table 6 reports percent abundance (log transformed) of each taxon in each sampling site.

Olmstead-Tukey diagrams are shown in Fig. 3. The Reserve sites and the Sin Nombre were joined together in one diagram because they were not found to be significantly different in the ANOSIM analysis. Cropped streams and the Arregui are shown separately because they were significantly different from the others in the ANOSIM analysis. Baetidae and Caenidae were dominant in the Reserve and livestock streams and were rare or absent from the cropped streams. Hydrobiomorpha (Hydrophilidae) and Libellulidae were dominant in the Reserve and Sin Nombre streams and absent from the other streams. Zygoptera was dominant in all streams except the cropped stream Gato.

By contrast, $P$. canaliculata (Ampullariidae) was dominant at the cropped sites while being occasional or rare at the other sites. Sphaeriidae and Aeshnidae were dominant in the Remes, were absent in the Gato and Arregui and were occasional in the Reserve and Sin Nombre streams.

Table 6 Values of average abundance (log transformed) of the taxa that contributed to the sites' similarity in the SIMPER analysis

\begin{tabular}{llllllll}
\hline Taxa & Co & De & Mo & Ar & SN & Re & Ga \\
\hline Hyalella & 3.71 & 4.92 & 4.45 & 3.65 & 3.9 & & 1.65 \\
Zygoptera & 2.35 & 3.39 & 1.7 & 1.31 & 2.95 & 1.46 & \\
Chironomidae & 2.2 & & 1.57 & 1.83 & 1.64 & 1.19 & 0.71 \\
B. peregrina & 1.01 & 3.57 & 3.07 & & 3.92 & 1.24 & \\
Hirudinea & & 0.66 & 1.19 & & & 1.61 & 0.9 \\
Ostracoda & & 1.2 & 1.57 & & 2.92 & 1.36 & \\
Baetidae & 1.33 & 1.82 & 1.21 & 0.88 & & & \\
Tropisternus & 1.12 & 1.15 & 0.97 & & 1.58 & & \\
Bidessini & 1.35 & & & & & 0.65 & 0.58 \\
Gundlachia & & 0.69 & & & 1.44 & 0.55 & \\
Stratiomyidae & 1.55 & 1.19 & & & & 0.16 & 0.2 \\
Hydrocanthus & 1.09 & 1.01 & & & & & \\
Caenidae & 0.62 & & & 1.91 & & & \\
Laccophilus & 0.89 & & & & 1.51 & & \\
Curculionidae & & & 1.27 & & 1.03 & & \\
$P$. canaliculata & & & & & & 1.54 & 0.58 \\
\hline
\end{tabular}

\section{Discussion}

Water flow in the Pampasic streams was rather low in the dry summer. The low gradient, and organic matter accumulation at the bottom, probably contributed to the low oxygen concentrations observed in periods of high temperatures, in the two streams with the largest macrophyte cover (Remes and Sin Nombre). Invertebrate abundance and richness were comparatively high in both streams, coinciding with the low measured concentrations, suggesting that the effect on the assemblage composition is small. Some crustaceans and Planorbidae, well represented in the studied streams, are tolerant of low oxygen concentrations. The reported $96 \mathrm{~h} \mathrm{LC50}$ of the amphipod Hyalella azteca is $0.3 \mathrm{mg} / \mathrm{l}$ while Planorbidae can survive $24 \mathrm{~h}$ of anoxia (EPD 2016).

Higher nutrient concentrations were measured in the streams adjacent to cropped plots. None of the studied streams receive point sources. Peak SRP concentrations in Remes and Sin Nombre together with low oxygen concentrations measured at the surface suggest SRP release from anoxic sediments. Concentrations remained seven times higher in the cropped stream (Table 2). Mugni (2009) reported that the nutrient concentration in runoff was affected by crop fertilization in adjacent plots, in the Remes, the same site sampled in the present study. The first runoff event after fertilizer application showed the highest nutrient concentrations. Increased nutrient concentrations in cropped watersheds have repeatedly been reported in the literature. Gabellone et al. (2005) observed higher nutrient concentrations in the upper basin of the Salado River, in Buenos Aires province, Argentina, where intensive cultivation is the main land use, and decreasing downstream, where the river drains lower lands where livestock raising is the main activity. Jarvie et al. (2008) studied the basin of the Taw River, in England. In the upper basin, where extensive livestock raising is dominant, $85 \%$ of SRP determinations fell below the detection limit (7 $\mu \mathrm{g}$ P/l). In the lower basin, where cattle breeding at higher densities in fertilized grassland and wheat crops are dominant, SRP concentrations were 5 times higher, and nitrate amounted to $17 \mathrm{mg} / \mathrm{l}$.

Higher insecticide concentrations were determined in the cropped streams. Much lower concentrations were detected in the Reserve, where applications are not performed. Detected pesticides have a large persistence. DDT half-life in soil is 1.1-3.4 years (USEPA 2002). Heptachlor and DDT are volatile compounds banned in the eighties. Endosulfan is also persistent; mean half-lives of $\alpha, \beta$ and total endosulfan in soil are 27.5, 157 and 1336 days, respectively, under aerobic conditions (GFEA-U 2007; US EPA 2007a). Endosulfan sulfate, the degradation product 


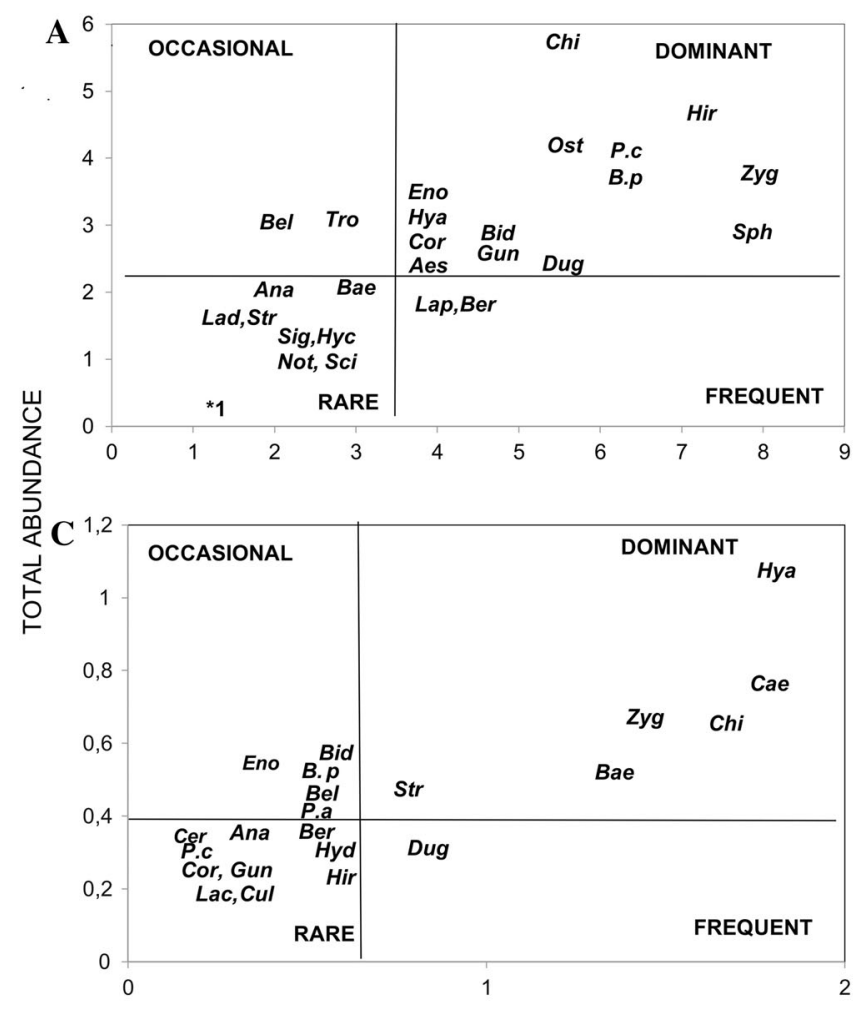

FRECUENCY (\%)

Fig. 3 Olmstead-Tukey diagram. a Remes. (*1) Neo (Neoplea), Aph (Aphidoidea), Cry (Crysomelidae), Der (Derallus), Cre (Crenitis), Cer (Ceratopogonidae) b Gato. (*1) Cur (Curculionidae), Cry, Hyc (Hydrocanthus), Ber (Berosus), Lad (Lacodytes), Cul (Culicidae), Gun (Gundlanchia), Ost (Cyprididae). c Arregui. (*1) Eph (Ephydridae), Hel (Helochares), Der (Derallus), Cur, Aph. d Reserva and Sin

from the parent isomers, is also toxic (Barry 1996). Measured endosulfan concentrations in the present study are consistent with reported air endosulfan concentration at 29 locations in the Pampasic region by Astoviza et al. (2015). Highest concentrations were determined at an orchard site, in Olmos, close to the Gato and Remes streams, attaining values that represent the highest in the literature (mean $15 \mathrm{ng} / \mathrm{m}^{3}$ ), and concentrations orders of magnitude lower were measured in Magdalena $\left(0.17 \mathrm{ng} / \mathrm{m}^{3}\right)$, in a livestock area, close to the Reserve streams sampled in the present study. The occurrence of endosulfan far from the application sites is well known; in the environment, it can undergo long-range atmospheric transport to remote regions, like the Antarctic (Weber et al. 2010).

Hyalella curvispina has repeatedly been used as a sentinel organism for environmental impact assessment in Pampasic streams because of its extensive geographic distribution, its commonly high abundance and its high sensitivity to pesticide exposure (Jergentz et al. 2004a, b). Mugni et al. (2011) reported the occurrence of toxicity pulses to $H$. curvispina in stream and runoff water in coincidence with the first rains after pesticide application in
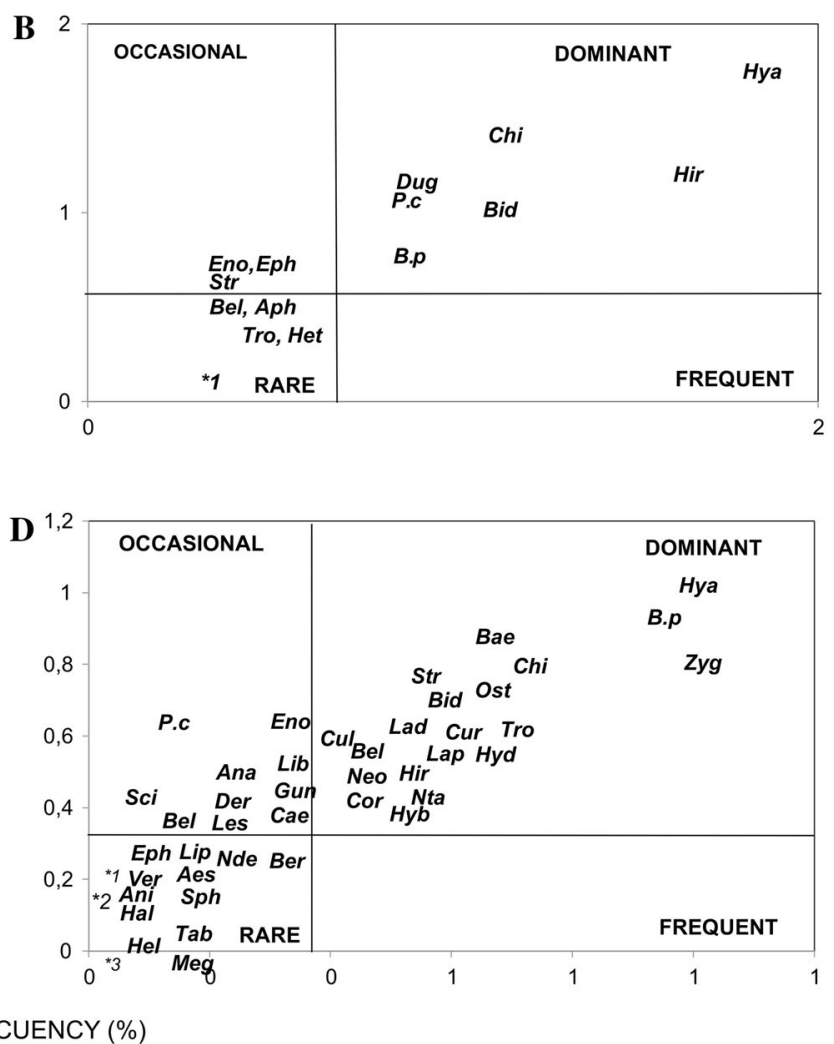

Nombre. (*1) Cry, Hyc, Tip (Tipulidae), Hyd; (*2) Cul, Lep (Lepidoptera), Sim (Simulidae), P.a (P. argentinus); (*3) Coe (Coenagrionidae), Sig (Sigara), Cur, Sta (Staphylinidae), The (Thermonectus), Lan (Lancetes), Elm (Elmidae), Het (Heteroceridae), Mus (Muscidae), Sph (Sphaeriidae 1 y 2)

the adjacent crop at Remes, the same site sampled in the present work. Jergentz et al. (2004a, b) detected toxicity pulses associated with rain events in other Pampasic streams during the period of insecticide application. Mugni et al. (2012) and Paracampo et al. (2012) studied the toxicity persistence in runoff water from experimental soy plots following endosulfan, chlorpyrifos and cypermethrin crop applications and reported that runoff water was toxic to $H$. curvispina up to roughly one month after application. Available information is consistent with the lower densities of $H$. curvispina in Remes $\left(21 \mathrm{ind} / \mathrm{m}^{2}\right)$ while it was the dominant at the Reserve and livestock sites $\left(1081 \mathrm{ind} / \mathrm{m}^{2}\right.$ in the Morales and $2408 \mathrm{ind} / \mathrm{m}^{2}$ in the Destino) and suggests insecticide toxicity as the cause.

Liess and Von der Ohe (2005) classified the macroinvertebrate species of German streams according to their sensitivity to insecticide exposure: The most sensitive were called "SPEAR" (SPEcies At Risk) and the less sensitive "SPEnotAR" (species not at risk). Further, they assessed the proportion of sensitive species in the assemblages with pesticide exposure. Most of the dominant taxa in the cropped streams of the present study belong to species 
considered as tolerant by Liess and Von der Ohe (2005). Ephemeroptera, repeatedly quoted in the literature as a sensitive taxon (Leonard et al. 1999; Castillo et al. 2006; Liess and Von der Ohe 2005), were well represented in the livestock and Reserve streams (90-409 ind $/ \mathrm{m}^{2}$ ), while Caenidae was absent from both cropped streams and Baetidae was absent in the Gato and present at low densities in a few samplings in the Remes $\left(1-4 \mathrm{ind} / \mathrm{m}^{2}\right)$.

As previously stated, during the sampling period an exceptional rain event of $273 \mathrm{~mm}$ occurred on April 2, 2013 in the basins of Remes and Gato streams. The vegetation debris retained by the fences of the adjacent plots suggests a several fold increase in water depth and consequently a huge discharge increase. It is interesting to note, however, that invertebrate abundances were not statistically different between the previous sampling and that which followed 15 days later, suggesting a large capacity for resilience among the local assemblages. Similarly, Liess and Von der Ohe (2005); Liess and Schulz (1999); Liess et al. (2008) reported small effect of hydraulic stress on the stream invertebrate community.

The invertebrate assemblages of the two streams draining basins in which livestock raising was the main land use were significantly different. The assemblage composition of the Arregui stream was different from all others except the Reserve stream Confluencia and the CLUSTER analysis grouped them together. S. californicus was the dominant macrophyte at both sampling sites. Scirpus contains thin and long, not branched stems, of low structural complexity. The Confluencia attained a higher Scirpus cover and in summer was accompanied by the floating macrophyte Azolla, resulting in higher invertebrate abundance.

The invertebrate assemblage in the Sin Nombre livestock stream was not significantly different from the Destino and Morales Reserve streams and the Cluster analysis grouped them together. These streams contained floating and emergent macrophytes. The Sin Nombre contained a large cover of $L$. peploides. This macrophyte contains highly branched stalks supporting numerous submerged and emergent leaves. Macrophyte complexity has been associated with high abundance and richness of macroinvertebrates (Ferreiro et al. 2014). While the effect on richness has been attributed to an increase in the number of niches, the effect on abundance has been explained by a higher availability of space for small individuals, refuge and/or food. Duggan et al. (2001) considered that vegetation architecture and growth form determine the macroinvertebrate composition. Walker et al. (2013) studied the macroinvertebrate community of various habitats represented by macrophytes of different structural complexity and growth form. A habitat consisting of macrophyte growth forms with highly branched and dissected leaves provide more food resources and microhabitats supporting larger numbers of macroinvertebrates than macrophytes with firm, undissected stalks and leaves. Ferreiro et al. (2014) performed experiments of macrophyte and artificial substrate colonization by invertebrates in the laboratory and in situ in a Pampasic stream, concluding the preference of Hyalella sp. for complex structures, suggesting that active selection may be important for macroinvertebrate distribution on substrata of contrasting complexity. Similarly, Hansen et al. (2011) found an active selection of complex macrophytes and plastic imitations by Gammarus oceanicus (Amphipoda).

\section{Conclusion}

Land use in the basin affects the invertebrate assemblage composition in Pampasic streams. Higher pesticide and nutrient concentrations were determined at sites adjacent to cropped plots. Higher insecticide concentrations in stream sediments resulted from crop applications. Higher nutrient concentrations at the cropped streams were related to fertilizer applications. The invertebrate assemblage composition at these sites was significantly different from those located in a Reserve and in basins with livestock. Present evidence suggests that exposure to agrochemicals is the main cause of the observed differences in the invertebrate assemblage composition.

The assemblage composition of the 2 livestock streams was different. One of the livestock streams was similar to one of the Reserve streams, both sites sharing a comparative low macrophyte cover of Scirpus californicus, while the composition of the other livestock stream was similar to that of the other Reserve streams, sharing a more complex macrophyte community of mixed floating and emergent macrophytes. It is therefore suggested that in Pampasic streams the macrophyte cover and dominance has a stronger influence on the invertebrate assemblages than the eventual effect of livestock on natural grasslands in the adjacent fields.

It is suggested that the ongoing agricultural intensification induces a change toward a pollution tolerant fauna with increased abundance of Ostracoda, Glossiphoniidae, Gundlanchia (Ancylidae), P. canaliculata (Ampullariidae), Sphaeriidae and Dugesiidae and decreased abundance or absence of sensitive species such as Hyalellidae, Caenidae, Baetidae, Curculionidae, Hydrobiomorpha (Hydrophilidae) and Libellulidae. These taxa represent promising candidates for being utilized as regional indicators of agrochemical contamination. We conclude that monitoring macroinvertebrate communities can be a powerful tool in the assessment of ecological effects of crop production in Pampasic streams. 
Acknowledgements The authors thank the reviewers and the editor for their valuable comments and suggestions. This study was supported by grants from the Agencia Nacional de Promoción Científica y Tecnológica, Argentina; (PICT 2010-0446) and the Consejo Nacional de Investigaciones Científicas y Técnicas, CONICET, Argentina; (PIP $2011 \mathrm{~N}^{\circ}$ 0180)

\section{References}

Aizen MA, Harder LD (2009) The global stock of domesticated honey bees is growing slower than agricultural demand for pollination. Curr Biol 19:915-918

APHA (1995) Standard methods for the examination of water and wastewater. American Public Health Association, 19th edn. American Public Health Association, Washington, DC

Astoviza MJ, Cappelletti N, Bilos C, Migoya MC, Colombo JC (2015) Massive airborne Endosulfan inputs related to intensive agricultura in Argentina's Pampa. Chemosphere 144:1459-1466

Athor J (ed) (2009) Parque Costero del Sur-Naturaleza, conservación y patrimonio cultural. Fundación de Historia Natural "Félix de Azara". Buenos Aires, p 528

Barry MJ (1996) Effects of an organochlorine pesticide on different levels of biological organization in Daphnia. Ecotoxicol Environ Saf 34:239-251

CASAFE (2013) Cámara de Sanidad Agropecuaria y Fertilizantes, Buenos Aires, Argentina. http://www.casafe.org/sobrelaindus tria.htm. Accessed on Nov 2013

Castillo LE, Martinez E, Ruepert C, Savage C, Gilek M, Pinnock M, Solis E (2006) Water quality and macroinvertebrate community response following pesticide applications in a banana plantation, Limon, Costa Rica. Sci Total Environ 367:418-432

CIAFA (Cámara de la Industria Argentina de Fertilizantes y Agroquímicos) (2016) (http://www.ciafa.org.ar/) http://www. ciafa.org.ar/informes/Mercado/ConsumoFertilizantes2013.pdf. Accessed 18 Feb 2016

Clarke KR, Gorley RN (2001) PRIMER v5: User Manual/Tutorial PRIMER-E: Plymouth Routines in Multivariate Ecological Research, p 91

Clarke KR, Warwick RM (2001) Change in Marine Communities, an approach to statistical analysis and interpretacion, 2nd edn. PRIMER-E: Plymouth Routines in Multivariate Ecological Research

Dominguez E, Fernandez HR (eds) (2009) Macroinvertebrados bentónicos. Sistemática y biología. $1^{\mathrm{a}}$ ed. Tucumán. Fundación Miguel Lillo, p 656

Duggan IC, Green JD, Thompson K, Shiel RJ (2001) The influence of macrophytes on the spatial distribution of littoral rotifers. Freshw Biol 46:777-786

EPD (Environmental Protection Division) (2016) Water Quality Ambient. Water quality criteria for dissolved oxygen. Aquatic life (freshwater, marine and sediment). Government of British Columbia, Canada. http://www.env.gov.bc.ca/wat/wq/BCguide lines/do/do-03.htm

Ferreiro N, Feijoó C, Giorgi A, Rosso J (2014) Macroinvertebrates select complex macrophytes independently of their body size and fish predation risk in a Pampean stream. Hydrobiologia. doi:10.1007/s10750-014-1953-y

Gabellone N, Claps M, Solari L, Neschuk N (2005) Nutrients, conductivity and plankton in a landscape approach to a Pampean saline lowland river (Salado River, Argentina). Biogeochemistry 75:455-477

GFEA-U (2007) Endosulfan. Draft Dossier prepared in support of a proposal of endosulfan to be considered as a candidate for inclusion in the CLRTAP protocol on persistent organic pollutants. German Federal Environment Agency-Umweltbundesamt Berlin. https://www.unece.org/fileadmin/DAM/env/lrtap/ TaskForce/popsxg/2004/Dossier_Endosulfan.2004.pdf

Hansen JP, Wikstrom SA, Axemar H, Kautsky L (2011) Distribution differences and active habitat choices of invertebrates between macrophytes of different morphological complexity. Aquat Ecol 45:11-22

Hunt L, Bonetto C, Resh VH, Forsin Buss D, Fanelli S, Marrochi N, Lydy MJ (2016) Insecticide concentrations in stream sediments of soy production regions of South America. Sci Total Environ 547:114-124

Hurtado MA, Giménez JE, Cabral MG (eds) (2006) Análisis ambiental del partido de La Plata: Aportes al ordenamiento territorial, $1^{\mathrm{a}}$ edn. Buenos Aires, Consejo Federal de Inversiones, p 125

Jarvie HP, Haygarth PM, Neal C, Butler P, Smith B, Naden PS, Joynes A, Neal M, Wickham H, Armstrong L, Harman S, Palmer-Felgate EJ (2008) Stream water and quality along an upland-lowland rural land use continuum, south west England. J Hydrol 350:215-231

Jergentz S, Mugni H, Bonetto C, Schulz R (2004a) Runoff-related endosulfan contamination and aquatic macroinvertebrate response in rural basins near Buenos Aires, Argentina. Arch Environ Contam Toxicol 46(3):345-353

Jergentz S, Pessacq P, Mugni H, Bonetto C, Schulz R (2004b) Linking in situ bioassays and dynamics of macroinvertebrates to assess agricultural contamination in streams of the Argentine Pampa. Ecotoxicol Environ Saf 59:133-141

Jergentz S, Mugni H, Bonetto C, Schulz R (2005) Assessment of insecticide contamination in runoff and stream water of small agricultural streams in the main soybean area of Argentina. Chemosphere 61(6):817-826

Leonard A, Hyne V, Lim R, Chapman J (1999) Effect of endosulfan runoff from cotton fields on macroinvertebrates in the Namoi River. Ecotoxicol Environ Saf 42:125-134

Liess M, Schulz R (1999) Linking insecticide contamination and population response in an agricultural stream. Environ Toxicol Chem 18(9):1948-1955

Liess M, Von der Ohe P (2005) Analyzing effects of pesticides on invertebrate communities in streams. Environ Toxicol Chem 24:954-965

Liess M, Schäfer RB, Schriever CA (2008) The footprint of pesticide stress in communities-species traits reveal community effects of toxicants. Sci Total Environ 406:484-490

Lorenzen CJ (1967) Determination of chlorophyll and phaeopigments: spectrophotometric equations. Limnol Oceanogr 12:343-346

MAGPyA (Ministerio de agroindustria ganadería y pesca) (2016) (http://www.agroindustria.gob.ar) http://www.siia.gov.ar/_apps/ siia/estimaciones/estima2.php. Accesses 9 Feb 2016

Marino D, Ronco A (2005) Cypermethrin and chlorpiryfos concentration levels in surface water bodies of the Pampa Ondulada, Argentina. Bull Environ Contam Toxicol 75(4):820-826

Merritt RW, Cummins KW, Berg MB (eds) (2008) An introduction to the aqugtic insects of North America. Kendall-Hunt, Dubuque, p 1158

Mugni H (2009) Concentración de nutrientes y toxicidad de pesticidas en aguas superficiales de cuencas rurales. Tesis doctoral, Universidad de La Plata, p 140

Mugni H, Ronco A, Bonetto C (2011) Insecticide toxicity to Hyalella curvispina in runoff and stream water within a soybean farm (Buenos Aires, Argentina). Ecotoxicol Environ Saf 74:350-354

Mugni H, Demetrio P, Paracampo A, Pardi M, Bulus G, Bonetto C (2012) Toxicity Persistence in Runoff Water and Soil in Experimental Soybean Plots Following Chlorpyrifos Application. Bull Environ Contam Toxicol 89:208-212 
Paracampo A, Mugni H, Demetrio P, Pardi M, Bulus G, Asborno M, Bonetto C (2012) Toxicity persistence in runoff from experimental soybean plots following pesticide applications. J Environ Sci Health Part B 47:761-768

Pengue W (2000) Cultivos transgénicos ¿Hacia dónde vamos?. Lugar Editorial S. A, Buenos Aires, p 190

Schafer RB, Caquet T, Siimes K, Mueller R, Lagadic L, Liess M (2007) Effects of pesticides on community structure and ecosystem functions in agricultural streams of three biogeographical regions in Europe. Sci Total Environ 382:272-285

Schulz R (2004) Field studies on exposure, effects, and risk mitigation of aquatic nonpoint-source insecticide pollution: a review. J Environ Qual 33:419-448

Sokal RR, Rohlf JF (1979) Biometría. Blume, Madrid

Soldner M, Stephen I, Ramos L, Angus R, Claire Wells N, Grosso A, Crane M (2003) Relationship between macroinvertebrate fauna and environmental variables in small streams of the Dominican Republic. Water Res 38:863-874

Stehle S, Schulz R (2015) Agricultural insecticides threaten surface waters at the global scale. In: Blais JM (ed) University of Ottawa, Ottawa, Canada, March 2015. www.pnas.org/cgi/doi/10. 1073/pnas. 1500232112

USEPA (2002) Methods for measuring the acute toxicity of effluents and receiving waters to freshwater and marine organisms, 5th edn. EPA-821-R-02-012, Washington, DC
USEPA (2007) Report on the environment: science report. https:// cfpub.epa.gov/ncea/risk/recordisplay.cfm?deid=140917

USEPA (2007a) Addendum to the ecological risk assessment for Endosulfan, Memorandum to special review and preregistration branch. EPA-HQ-QPP-202-0262-0063. http://chm.pops.int/Por tals/0/Repository/Endosulfan2008/UNEP-POPS-POPRC-END08-USA-3.English.PDF

USEPA (2007b) Note to reader. Endosulfan readers guide. EPA-HQOPP-2002-0262-0057

USEPA method 8081 A (1996) Organochlorine pesticides by gas chromatography http://www.caslab.com/EPA-Methods/PDF/ 8081a.pdf

Walker PD, Wijnhoven S, van der Velde G (2013) Macrophyte presence and growth form influence macroinvertebrate community structure. Aquat Bot 104:80-87

Weber J, Halsall CJ, Muir D, Teixeira C, Small J, Solomon K, Hermanson M, Hung H, Bidleman T (2010) Endosulfan, a global pesticide: a review of its fate in the environment and occurrence in the Arctic. Sci Total Environ 408:2966-2984

You J, Weston DP, Lydy MJ (2004) A sonication extraction method for the analysis of pyrethroid, organophosphate, and organochlorine pesticides from sediment by gas chromatography with electron-capture detection. Arch Environ Contam Toxicol 47(2):141-147 